\title{
SWADHARMA WANITA HINDU DI DESA PAKRAMAN MAS KABUPATEN GIANYAR
}

\author{
I Gusti Agung Istri Agung \\ Universitas Hindu Negeri I Gusti Bagus Sugriwa Denpasar \\ Email: agungistriagung@gmail.com
}

\begin{abstract}
The purpose of this study is to obtain broader information and to provide explanations to various parties regarding the existence of Hindu women in practicing Swadharna in Mas Village, Ubud District, Gianyar Regency. The method used in the study, determining the type and source of data, determining the interview instrument, and studying documents, analyzing data and presenting the results of data analysis. Based on the description and results of the analysis of the existence, constraints and efforts of Hindu women's swadharma in Mas Village, Ubud District, Gianyar Regency, described above, there are several things that can be concluded, namely as follows. The existence of Hindu women in Mas Village can be grouped into three groups. The existence of practicing swadharma can be grouped into three. The existence of practicing swadharma in the family. Existence in carrying out swadharma in the world of work.
\end{abstract}

\section{Keywords: Swadharma; Hindu Woman.}

\begin{abstract}
Abstrak
Tujuan penelitian ini yaitu untuk mendapatkan informasi yang lebih luas dan dapat memberikan penjelasan kepada berbagai pihak mengenai keberadaan wanita Hindu dalam menjalankan swadharna di Desa Mas, Kecamatan Ubud, Kabupaten Gianyar. Metode yang digunakan dalam penelitian, penentuan jenis dan sumber data, penentuan intrumen wawancara, dan studi dokumen, analisis data serta penyajian hasil analisis data. Berdasarkan deskripsi dan hasil analisis eksistensi, kendala dan upaya swadharma wanita Hindu di Desa pakraman Mas, Kecamatan Ubud Kabupaten Gianyar yang diuraikan di atas terdapat beberapa hal yang menjadi simpulan yaitu sebagai berikut. Eksistensi wanita Hindu di Desa Mas dapat dikelompokkan menjadi tiga. Eksistensi dalam menjalankan swadharma dapat dikelompokkan menjadi tiga. Eksistensi dalam menjalankan swadharma di keluarga. Eksistensi dalam menjalankan swadharma di dunia kerja.
\end{abstract}

\section{Kata Kunci : Swadharma; Wanita Hindu.}

\section{PENDAHULUAN}

Kemajuan ilmu pengetahuan dan teknologi menuntut semua pihak bisa ikut serta dalam pemanfaatan kemajuan ilmu pengetahuan dan teknologi tersebut. Kemajuan ilmu pengetahuan dan teknologi juga menyentuh kehidupan sosial di Bali, khususnya bagi kaum wanita Hindu. Dewasa ini kaum wanita Hindu tidak mau ketinggalan untuk bersaing dengan kaum laki-laki di dunia pendidikan maupun di dunia kerja. Menerut Wirartha (2000) meskipun prospek pekerja perempuan cukup baik dilihat dari pertumbuhan angkatan kerja perempuan lebih cepat 
dari angkatan kerja laki-laki, namun tuntutan persamaan hak atas perolehan gaji dengan lakilaki belum sepenuhnya berhasil. Kini tidak sedikit dari wanita Hindu berlomba-lomba untuk menempuh pendidikan sampai perguruan tinggi. Kini anak perempuan Hindu di Bali sudah mendapat hak untuk dapat menempuh pendidikan layaknya anak laki-laki. Di dunia pendidikan anak perempuan tidak kalah saing dalam prestasi dengan anak laki-laki. Fenomena demikian menunjukkan bahwa gerakan emansipasi wanita yang diperakarsai oleh salah satu pahlawan wanita yaitu R.A Kartini tidak sia-sia.

Wanita Hindu di Bali mulai menunjukkan eksistensinya dalam kehidupan keluarga, masyarakat, bangsa dan negara. Peran serta wanita di dalam keluarga sangat berarti. Wanita sebagai istri dan ibu dalam keluarga memiliki peranan penting dalam keharmonisan keluarga dan perkembangan mental anak-anaknya. Selain mengurus keluarga, kini kaum wanita juga ikut serta dalam membantu keuangan keluarga. Wanita Hindu di Bali tidak mau hanya bergerak sebagai pengurus rumah tangga hanya bisa meminta kepada suami untuk keperluan biaya rumah tangga. Banyak kaum wanita kini mulai ikut serta dalam membanu Keuangan keluarga dengan bekerja sambilan di rumah maupun di luar rumah. Bahkan beberapa kaum ibu yang bisa bejuang seorang diri untuk memberi penghidupan kepada anak-anak, merupakan salah satu bukti yang wanita juga bisa berperan sebagai kepala keluarga yang bertanggung jawab atas kehidupan keluarganya layaknya seperti seorang ayah.

Kehidupan sosial masyarakat juga tidak dapat terlepas dari peran serta kaum wanita. Kaum laki-laki dan wanita saling bekerjasama untuk membangun suatu masyarakat yang harmonis. Kaum laki-laki dan kaum wanita memiliki peranan yang sama-sama penting bagi kesuksesan dan kemajuan kehidupan bermasyarakat. Terlebih lagi dalam kehidupan sosial masyarakat Hindu di Bali yang syarat akan pelaksanaan upacara keagamaan. Persiapan pelaksanaan upacara keagamaan yang dilaksanakan upacara keagamaan. Persiapan pelaksanaan upacara keagamaan yang dilaksanakan masyarakat Hindu di Bali lebih didominasi oleh kegiatan yang dikerjakan oleh kaum wanita. Seperti misalnya dalam pelaksanaan piodalan pada suatu pura yang dipersiapkan dalam waktu tujuh hari, kegiatan yang dikerjakan oleh kaum wanita bisa sampai lima hari, sedangkan kegiatan yang dikerjakan oleh kaum laki-laki paling hanya membutuhkan waktu satu atau dua hari. Keadaan yang demikian menunjukkan bahwa wanita sangat berperan penting dalam kehidupan bermasyarakat. Dewasa ini banyak kaum wanita yang ikut berperan aktif di dunia politik. Tidak jarang juga kini suatu wilayah kelurahan, kecamatan, kabupaten, dan provinsi yang dipimpin oleh seorang wanita. Ketika kaum wanita diberi kesempatan untuk menunjukkan eksistensinya sesungguhnya kaum wanita tidak kalah saing degan kaum laki-laki. Kaum wanita juga bisa menunjukkan prestasi layaknya kaum lakilaki.

Di tengah kesibukan wanita Hindu untuk sama-sama mengisi profesi dalam keluarga, masyarakat, berbangsa dan bernegara, kini muncul permasalahan baru tentang kewajiban wanita dalam keluarga dan masyarakat. Bila istri bekerja bagaimana dengan peran dan kewajibannya sebagai istri, ibu dan sebagai anggota masyarakat? Seorang ibu rumah tangga yang bekerja di luar rumah sering mendapat hujatan karena tidak bisa maksimal mengurus suami dan anak-anaknya. Ketika dalam keluarga terjadi masalah pada anak yang pertama disalahkan dan mendapat hujatan adalah seorang istri. Bahkan tidak jarang hujatan itu muncul dari selama kaum wanita. Wanita yang bekerja sering kali dianggap melalaikan kewajiban utamanya sebagai istri dan ibu dalam keluarga.

Wanita Hindu di Bali yang terjun di dunia kerja juga harus membagi waktu untuk bisa mengikuti kegiatan di masyarakat. Terlebih lagi sebagai wanita Hindu di Bali yang disibukkan dengan seder kegiatan adat. Ketika wanita Hindu di Bali tidak bisa mengikuti kegiatan adat secara maksimal dengan alasan karena bekerja, maka hal tersebut akan menjadi perbincangan di kalangan kaum wanita lainnya. Tidak jarang keadaan demikian menyebabkan wanita Hindu di Bali yang tidak bisa mengikuti kegiatan adat secara maksimal karena bekerja mendapat sanksi khusus dari pengurus desa. Sanksi tersebut tidak hanya sebatas sanksi secara materi 
bahkan sampai pada sanksi moral, seperti diperbincangkan dan dikucilkan. Keadaan demikian menyebabkan terjadinya ketidak harmonisan dalam masyarakat.

Kerasnya aturan adat yang diterapkan dalam kehidupan masyarakat Hindu di Bali meyebabkan masyarakat Hindu di Bali semakin terjepit. Apabila bagi wanita Hindu yang juga berprofesi sebagai wanita karier. Aturan adat yang mengikat sering kali berbeturan dengan aturan di dunia kerja. Pada situasi demikian mau tidak mau wanita Hindu di Bali harus memilih salah satu aturan yang diikuti. Pada suatu keadaan bisa jadi wanita Hindu memilih untuk bolos dari tempat kerja untuk mengikuti kegiatan adat. Atau sebaliknya memilih untuk melanggar atauran adat dengan sederet konsekuensi sanksi yang akan didapat nantinya. Keadaan demikian menyebabkan wanita Hindu di Bali berada pada posisi yang sulit. Terlalu sering mengambil ijin di tempat kerja dapat menyebabkan diberhentikan dari pekerjaan. Terlalu sering melanggar aturan adat juga menyebabkan sanksi yang diberlakukan akan semakin meningkat.

Fenomena demikian terjadi pada masyarakat di Desa Pakraman Mas, Kecamatan Ubud, Kabupaten Gianyar. Kini sudah banyak wanita Hindu di Desa Pakraman Mas ikut serta mencari nafkah untuk membantu keuangan keluarga. Wanita Hindu di Desa Pakraman Mas tidak lagi hanya berdiam diri di rumah dan hanya mengandalkan keuangan keluarga dari suami saja. Banyak wanita Hindu di Desa Pakraman Mas yang ikut berkarier di luar rumah sesuai dengan profesinya. Sebagai wanita yang berkarier di luar rumah, wanita Hindu di Desa Pakraman Mas tidak melalaikan tugas dan swadharma di rumah sebagai istri dan sebagai ibu bagi anak-anaknya.

Keikutsertaan wanita Hindu di Desa Pakraman Mas dalam membantu keuangan keluarga maka kewajiban atau swadharma wanita Hindu di Desa Pakraman Mas semakin bertambah. Keadaan tersebut membuat wanita Hindu di Desa Pakraman Mas, Kecamatan Ubud, Kabupaten Gianyar harus bisa membagi waktu dengan baik agar semua swadharma-nya dapat terlaksana. Wanita Hindu di Desa Pakraman Mas harus membagi waktu untuk dapat melaksanakan swadharma-nya di keluarga, di masyarakat, dan di tempat berkarier. Semua swadharma tersebut harus bisa dijalankan dengan baik agar tercapai keharmonisan dalam kehidupan di keluarga, masyarakat, maupun di dunia keraja. Menurut Manembu (2017) menyertakan perempuan dalam proses pembangunan bukanlah berarti hanya sebagai suatu tindakan yang dipandang dari sisi humanisme belaka. Namun peran yang dilakukan oleh perempuan dalam kesertaannya di bidang pembangunan merupakan tindakan dalam rangka mengangkat harkat serta kualitas dari perempuan itu sendiri. Apabila salah satu dari kewajiban tersebut tidak dapat dilaksanakan dengan baik tentunya akan menimbulkan ketidak teraturan dalam keluarga, masyarakat, dan di dunia kerja.

\section{METODE}

Jenis penelitian ini adalah penelitian kualitatif. Penelitian kualitatif merupakan jenis penelitian yang berusaha menggambarkan dan menginterpretasikan objek sesuai dengan apa adanya (Moleong, 2001:19). Penelitian ini dilakukan di Desa Pakraman Mas, Kecamatan Ubud, Kabupaten Gianyar. Dipilihnya Desa Pakraman Mas sebagai tempat penelitian karena peneliti memiliki beberapa pertimbangan. Pertimbangan pertama karena kehidupan sosial masyarakat di Desa Pakraman Mas tidak terlepas dari aspek kehidupan beragama yang dianut oleh masyarakatnya yaitu agama Hindu. Pertimbangan lain adalah karena kaum wanita Hindu di Desa Pakraman Mas sudah mulai ikut bersaing dengan laki-laki dalam menjalankan kehidupan baik di keluarga maupun di masyarakat. Selain itu kaum wanita Hindu di Desa Pakraman Mas tidak melalaikan swadharma-nya sebagai wanita baik di dalam kehidupan keluarga dan masyarakat. Jenis data yang digunakan penelitian ini adalah jenis data kualitatif, yaitu data yang terkumpul dokumen-dokumen, catatan lapangan, ucapan dan tindakan informan dan lain-lain dalam bentuk kalimat atau uraian. Data kuantitatif digunakan sebagai penunjang data lain dalam penelitian ini. 
Sumber data dalam penelitian adalah sumber data primer dan sumber data sekunder. Sumber data primer informan yang terkait dengan keberadaan wanita Hindu dalam menjalan swadharma di Desa Pakraman Mas. Sumber data sekunder berupa sumber tertulis yang relevan dan terkini seperti hasil penelitian, jurnal ilmiah, majalah, buku-buku yang relevan dan memenuhi syarat sebagai kajian pustaka penelitian. Informan dalam penelitian ini adalah kaum wanita Hindu yang berperan dalam kehidupan sosial agama di Desa Pakraman Mas, seperti ketua PKK, sarati banten, dan masyarakat Desa Pakraman Mas yang memiliki informasi terkait swadharma wanita Hindu di Desa Pakraman Mas. Teknik pengumpulan data pada penelitian ini dilakukan dengan observasi atau pengamatan langsung di lapangan, wawancara, dan studi dokumen.

\section{HASIL DAN PEMBAHASAN}

Wanita selalu berusaha untuk mengembangkan diri dari jaman ke jaman. Penggerakan emansipasi wanita masih memberi semangat bagi kaum wanita untuk selalu menunjukkan eksistensi. Pada jamannya R.A Kartini, wanita masih sangat sulit untuk bisa unjuk diri dalam menunjukkan kemampuannya dalam keluarga. Masyarakat dan kehidupan bernegara. Bahkan Negara Kesatuan Republik Indonesia pernah dipimpin oleh presiden wanita. Keadaan tersebut menunjukkan bahwa ketika wanita mendapatkan kesempatan maka wanita juga mampu mengisi posisi yang penting dalam setiap aspek kehidupan. Keadaan demikian sejalan dengan teori eksistensialisme yang menekankan pada manusia, yang mana manusia dipandang suatu makhluk yang harus bereksistensi, mengkaji cara manusia berada di dunia dengan kesadaran. Eksistensialisme didefinisikan sebagai usaha untuk memfilsafatkan sesuatu dari sudut pandang pelakunya, dibandingkan cara tradisional yaitu ari sudut pandang peneliti. Eksistensialisme berusaha membuang jauh-jauh segala penyempitan pandangan maupun penafsiran yang berat sebelah terhadap manusia. Dan Eksistensialisme menolak sifat obyektif didalam memandang manusia, karena eksistensialisme memandang manusia secara subyektif (Muzairi, 2002). Wanita selalu berusaha menunjukkan keberadaannya di dalam kehidupan sosial.

Wanita memegang peranan penting dalam kehidupan keluarga, bermasyarakat dan bernegara. Wanita di samping sebagai istri, ibu diharapkan aktif dalam organisasi dimana suami bekerja, karena status istri sebagai pendamping suami dan menurut informasi turut menentukan kondisi suami. Untuk dapat berpartisipasi dengan baik dalam masyarakat, pendidikan merupakan syarat yang mutlak (Soedarsono dan Murniatmo 1986). Wanita sebagai ibu dalam keluarga memiliki peranan yang sangat strategis dalam perkembangan keluarga. Wanita sebagai anggota masyarakat, khususnya dalam kehidupan masyarakat Hindu di Bali. Seiring dengan perkembangan jaman maka wanita juga ikut mengembangkan diri untuk menunjukkan eksistensi. Walaupun menurut Sofian (2014) peran ganda antara wanita karier dan ibu rumah tangga sering menimbulkan konflik pada diri wanita karier, sehingga seringkali wanita harus memilih antara karier atau rumah tangga.

Demikian juga dengan kaum wanita di Desa Pakraman Mas, Kecamatan Ubud, Kabupaten Gianyar. Kaum wanita di Desa Pakraman Mas, sudah banyak wanita yang terjun di dunia kerja untuk membantu keuangan keluarga. Dengan demikian maka swadharma wanita juga ikut bertambah. Selain bertugas untuk mengurus keluarga di rumah, kaum wanita di Desa Pakraman Mas juga ikut terlibat aktf dalam kegiatan di masyarakat. Dalam penelitian ini keberadaan wanita di Desa Pakraman Mas dibagi ke dalam tiga kelompok yaitu, keberadaan wanita Hindu dalam keluarga, keberadaan wanita Hindu dalam masyarakat dan keberadaan wanita dalam dunia kerja.

\section{Eksistensi Wanita Hindu dalam Keluarga di Desa Pakraman Mas}

Wanita mempunyai kedudukan yang mulia dalam ajaran agama Hindu. Dalam keluarga, wanita merupakan penentu kebahagiaan dan keharmonisan keluarga. Pustaka suci Manawa 
Dharma Sastra menguraikan bahwa wanita yang dimuliakan dalam keluarga maka akan membawa kebahagiaan dan keberhasilan yajna dalam keluarga.

Wanita merupakan sumber kebahagiaan keluarga. Wanita juga sebagai kunci kesuksesan pelaksanaan yajna dalam keluarga. Keberadaan wanita Hindu dalam keluarga mempunyai kedudukan yang sangat penting. Wanita mempunyai tanggung jawab yang penting dalam perkembangan kehidupan keluarganya. Wanita sebagai pendamping suami dan sebagai Pembina bagi anak-anaknya. Selain hal tersebut, wanita Hindu di Desa Pakraman Mas juga menunjukkan keberadaannya dengan ikut serta membantu keuangan keluarga. Eksistensi wanita Hindu dalam keluarga di Desa Pakraman Mas dapat dikelompokkan menjadi tiga kelompok yaitu, wanita sebagai pendamping suami, menjadi Pembina anak dalam keluarga, dan membantu keuangan keluarga.

Wanita sebagai pendamping suami dalam keluarga maka wanita tersebut berstatus sebagai istri. Kata istri berasal dari bahasa Sanskerta, dari kata str yang berarti 'mencintai atau menyayangi' (Surada, 2009:302). Wanita sebagai istri dalam keluarga merupakan symbol pancaran cinta dan kasih sayang dalam keluarga. Wanita Hindu sebagai istri dalam keluarga menunjukkan sebagai sosok yang penyayang sehingga dalam kehidupan rumah tangga.

Wanita sebagai pendamping suami merupakan patner bagi suami dalam keluarga. Keberadaan wanita sebagai istri merupakan tempat bagi suami untuk berbagi suka duka dalam kehidupan berkeluarga. Ketika suami dalam kesulitan maka istri harus dengan sabar mendampingi dan ikut serta mencari jalan keluar untuk masalah yang dihadapi oleh suaminya. Istri merupakan sandaran bagi suami dalam kehidupan berumah tangga. Dalam keadaan apapun istri harus selalu menunjukkan eksistensinya sebagai istri dalam keluarga.

Eksistensi wanita Hindu sebagai pendamping suami dalam keluarga akan semakin terlihat apabila wanita mampu mendampingi suaminya dalam keadaan apapun. Terlebih lagi apabila wanita mampu memberi jalan keluar terhadap masalah-masalah yang dihadapi suami. Wanita yang mampu mendampingi suami dalam segala keadaan dan mampu memberi jalan keluar terhadap masalah-masalah yang dihadapi oleh suami. Dalam ajaran agama Hindu terdapat banyak wanita yang mampu menjadi pendamping yang baik bagi suami. Salah satunya adalah Dewi Sita yang bersedia menderita mempertahankan kesetiaanya kepada suaminya Sri Rama. Keberadaan seorang perempuan yang dihargai di dalam sebuah keluarga, akan memberikan pengaruh positif terhadap keluarga tersebut. Dalam berbagai kitab suci agama Hindu dijelaskan bahwa suatu keluarga akan tampak bercahaya karena adanya sebuah penghargaan terhadap perempuan (Dewi, 2020).

Selain sebagai istri dalam keluarga, wanita Hindu juga menunjukkan keberadaannya sebagai ibu bagi anak-anaknya yang dilahirkannya. Wanita Hindu sebagai ibu dalam keluarga di Desa Pakraman Mas memiliki berbagai kewajiban dalam keluarga. Wanita Hindu sebagai ibu memiliki peranan yang sangat penting bagi perkembangan fisik dan mental anak-anaknya. Keberhasilan pendidikan budi pekerti seorang anak sangat tergantung pad acara pendidikan dini yang ditanamkan oleh seorang anak sangat tergantung pad acara pendidikan dini yang ditanamkan oleh seorang ibu. Wanita Hindu sebagai ibu dalam keluarga merupakan seorang guru bagi anak-anaknya. Ibu yang bertugas untuk menjadikan atau membentuk pertumbuhan rohani dan jasmani yang pertama bagi seorang anak. Wanita merupakan pendidik pertanam bagi seorang anak.

Ibu merupakan proses awal anak mengalami proses pembelajaran. Keberhasilan pendidikan anak sangat ditentukan oleh pola didik yang diterapkan oleh seorang ibu. Ibu memberikan pendidikan pada anak sejak masih di dalam kandungan. Eksistensi ibu sebagai pengasuh anak dalam keluarga sangat ditentukan dari kesuksesan anak-anaknya. Untuk menciptakan karakter yang kuat dan jiwa baik pada anak didalam keluarga, diperlukan terciptanya suasana keluarga yang harmonis dan dinamis, hal tersebut dapat tercipta jika terbangun koordinasi dan komunikasi dua arah yang kuat antara orang tua dan anak (Hyoscyamina, 2011). 
Ketika anak sudah lahir ibu memiliki peranan yang paling penting dalam setiap tahapan pertumbuhan si anak. Wanita sebagai ibu selalu berusaha sekuat tenaga agar kelak anaknya menjadi manusia yang baik sebagai penerus dari orang tuanya. Ini merupakan tugas yang diemban oleh wanita atau ibu. Anak yang memiliki budi pekerti luhur merupakan anak yang dilahirkan, dididik dan dibesarkan oleh seorang wanita yang mulia. Anak yang dididik dan dibesarkan dengan kasih sayang dan pola asuh yang benar oleh ibunya akan menjadi anak yang berguna bagi keluarga, masyarakat dan negara. Mengasuh anak memerlukan teknik dan kesabaran yang khusus.

Mengasuh dan mendidik anak jaman yang serba canggih dan modern seperti sekarang memerlukan ketelatenan khsusus. Ibu harus lebih pintar dari anak dalam pemahaman media elektronik seperti HP dan Leptop agar bisa mengawasi dan mengarahkan anak dalam menggunakan alat-alat elektronik yang canggih seperti sekarang. Wanita sebagai seorang ibu juga dituntut untuk bisa memahami dan menguasai teknologi agar mampu menjadi teman bermain sekaligus menjadi control anak dalam bermain. Karena jika anak tidak diawasi dan dikontrol dalam bermain dengan fasilitas berbagai alat yang berteknologi canggih anak akan menjadi salah pemahaman dan bisa terjerumus pada hal yang bersifat negatif.

Kemampuan seorang ibu dalam mengasuh anak dan mengarahkan anak sangat menentukan masa depan anak. Jika orangtua dapat menaggapi secara rileks dan penuh kepercayaan, anak akan mempunyai kesempatan besar untuk percaya kepada diri sendiri, kepada orang tua, dan masa depan (Djiwandono, 2005). Wanita sebagai ibu dalam keluarga harus mampu menunjukkan eksistensinya dalam berperan sebagai seorang ibu dalam keluarga dituntut untuk bisa menguasai dan memahami teknologi agar mampu mengarahkan anak dalam pemanfaatan teknologi tersebut. Setiap pola pengasuhan harus memberikan rasa nyaman tetapi juga diperkuat dengan batasan norma-norma yang menghindarkan anak pada perilaku menyimpang. Batasan tersebut sejatinya bukan bermaksud membuat anak terkekang namun justru membuat anak merasa terlindungi (Rakhmawati, 2015).

Selain sebagai istri dan ibu dari anak-anak dalam keluarga, wanita Hindu di Desa Pakraman Mas juga menunjukkan eksistensinya sebagai pembantu perekonomian dalam keluarga. Ditengah krisis ekonomi yang dialami bangsa Indonesia juga menuntut wanita Hindu di Desa Pakraman Mas untuk turut serta membantu perekonomian dalam keluarga. Tidak jarang wanita Hindu di Desa Pakraman Mas yang bekerja di rumah maupun di luar rumah untuk membantu keuangan keluarga.

Wanita yang mempunyai tanggung jawab untuk mengatur keuangan dalam keluarga. Ketika kebutuhan ekonomi dalam keluarga semakin meingkat, maka wanita harus mampu menunjukkan eksistensinya dalam membantu keuangan keluarga. Walaupun penghasilan tersebut tidak sebanding dengan penghasilan suami paling tidak ada yang ikut membantu suami sebagai tulang punggung keluarga. Wanita Hindu di Desa Pakraman Mas dalam keluarga sangat berperan dalam membantu keuangan keluarga. Eksistensi wanita Hindu di Desa Pakraman Mas dalam membantu perekonomian keluarga adalah dengan bekerja di rumah sebagai pengerajin seni patung maupun bekerja diluar rumah sebagai pegawai pendidik dan lainnya. Dari hasil kerja tersebut wanita Hindu di Desa Pakraman Mas dapat membantu meringankan beban keuangan keluarga.

Seiring perkembangan jaman, wanita Hindu di Desa Pakraman Mas ikut berinovasi dalam menunjukkan eksistensinya dalam keluarga. Berbagai peran yang dilakukan wanita Hindu di Desa Pakraman Mas menunjukkan bahwa wanita Hindu di Desa Pakraman Mas selalu berusaha untuk eksis agar dapat dipandang sebagai manusia yang dinamis sehingga ada unsur berbuat dan menjadi, manusia dipandang sebagai suatu realita yang terbuka dan belum selesai, dan berdasarkan pengalaman yang kongkrit. Wanita Hindu di Desa Pakraman Mas merupakan kumpulan manusia yang terbuka dan selalu bergerak, berinovasi sehingga selalu bisa eksis dalam kehidupan keluarga. Dalam usaha mempertahankan eksistensinya wanita Hindu di Desa Pakraman Mas selalu berupaya untuk terbuka menerima perkembangan jaman 
agar dapat berperan dalam perkembangan ilmu pengetahuan dan teknologi demi mempertahankan eksistensi wanita Hindu di lingkungan keluarga.

Diera globalisasi ini dengan ciri kemajuan dalam bidang ilmu dan teknologi, di sadari maupun tidak telah menggeser peran orang tua dalam memberikan pendidikan kepada anakanaknya. Pada masa lalu sebelum dikenal media televisi, tradisi bercerita sebelum tidur yang menyampaikan ajaran-ajaran moral dan etika agama masih dapat dijumpai, namun belakangan ini tradisi ini semakin menghilang, padahal peranan orang tua untuk melengkapi pendidikan agama yang diperoleh disekolah formal sangatlah dibutuhkan. Menyadari telah terjadi perubahan kondisi dan situasi saat ini dengan dampaknya yang tidak dapat dihindarkan, maka pendidikan Agama Hindu dalam keluarga sangatlah pentingguna membentengi dan membangun moral anak (Budiadnya, 2016).

\section{Eksistensi Wanita Hindu dalam Masyarakat di Desa Pakraman Mas}

Kehidupan bermasyarakat tidak terlepas dari peran kaum wanita di dalamnya. Demikian dengan kehidupan masyarakat di Desa Pakraman Mas tidak terlepas dari peran serta wanita dalam kehidupan masyarakatnya. Wanita Hindu di Desa Pakraman Mas memiliki peran yang sangat penting dalam kehidupan bermasyarakat. Desa Pakraman Mas memiliki peran yang sangat penting dalam kehidupan bermasyarakat. Desa Pakraman Mas merupakan salah satu desa Pakraman yang identik dengan berbagai kegiatan adat dan keagamaan yang melibatkan peran serta wanita Hindu di dalamnya. Sebagai wanita yang hidup di tengah masyarakat yang terikat oleh adat maka wanita Hindu di Desa Pakraman Mas akan disibukkan dengan berbagai kegiatan adat dalam masyarakat. Disamping kegiatan adat, wanita Hindu di Desa Pakraman Mas juga ikut seta dalam kegiatan adat, wanita Hindu di Desa Pakraman Mas juga ikut serta dalam kegiatan masyarakat di Desa dinas dalam ikatan organisasi PKK.

Eksistensi wanita Hindu di Desa Pakraman Mas sangat penting dalam pelaksanaan upacara keagamaan dan adat yang dilaksanakan di Desa Pakraman Mas. Wanita Hindu di Desa Pakraman Mas yang tergabung dalam kelompok serati banten merupakan kendali utama dalam setiap upacara agama yang dilaksanakan di Desa Pakraman Mas. Eksistensi wanita Hindu yang tergabung dalam kelompok penggerak PKK sangat penting dalam perkembangan kehidupan masyarakat di Desa Pakraman Mas. Sebagai penggerak PKK, wanita Hindu di Desa Pakraman Mas mempunyai tanggung jawab dalam penghayatan dan pengamalan Pancasila. Menanamkan sikap gotong royong dalam kehidupan bermasyarakat. Berusaha mengembangkan pendidikan dan keterampilan bagi kaum ibu. Pengembangan dalam pengelolaan sandang dan papan. Menanamkan tentang tata laksana rumah tangga agar terwujud keluarga yang harmonis. Segala kemungkinan ini menyebabkan orang semakin menyadari, bahwa pemahaman tentang arti dan fungsi rumah tangga bagi kaum perempuan hanya bisa diketahui apabila kita bisa mengungkap konsep rumah tangga dari segala pandangan keliru yang melingkupinya (Saptari, 1997).

Begitu banyak program kerja yang harus dilaksanakan wanita Hindu di Desa Pakraman Mas yang tergabung dalam kelompok penggerak PKK maka tanggung jawab yang besar berada di pundak wanita Hindu di Desa Pakraman Mas dalam kehidupan bermasyarakat. Sebagai penggerak PKK, wanita Hindu di Desa Pakraman Mas harus mampu melakukan berbagai pembaharuan informasi maupun aksi langsung kepada seluruh anggota masyarakat di Desa Pakraman Mas. Berbagai pembaharuan dilakukan oleh wanita Hindu di Desa Pakraman Mas menunjukkan bahwa wanita Hindu di Desa Pakraman Mas mampu tetap eksis dalam setiap perkembangan jaman. Wanita Hindu di Desa Pakraman Mas juga merupakan anggota masyarakat yang aktif dalam setiap kegiatan adat dan dinas di Desa Pakraman Mas.

Eksistensi wanita Hindu di Desa Pakraman Mas dalam kehidupan masyarakat di Desa Pakraman Mas adalah merupakan anggota masyarakat yang aktif dalam berbagai upacara yajna yang dilaksanakan di Desa Pakraman Mas. Pembuatan upacara dilaksanakan dengan sistem $n$ gayah secara suka rela dan tanpa adanya paksaan. Ngayah merupakan salah satu tradisi masyarakat Hindu di Desa Pakraman Mas dimana kegiatan kerja yang dilakukan merupakan 
bentuk ketulusan dan keiklasan. Semua wanita Hindu di Desa Pakraman Mas wajib datang ngayah dalam setiap upacara yajna yang dilaksanakan.

Sistem ngayah yang dilaksanakan oleh masyarakat Desa Pakraman Mas murni tanpa adanya tekanan. Kegiatan ngayah yang diterapkan tanpa tekanan karena tidak ada diterapkan sanksi apabila ada karma istri yang tidak melaksanakan ngayah. Ngayah merupakan warisan budaya masyarakat Bali. Dengan melaksanakan kegiatan ngayah wanita Hindu Bali ikut berperan dalam pelestarian budaya.

Setiap upacara yang dilaksanakan di Desa Pakraman Mas selalu melibatkan peran serta wanita Hindu di dalamnya. Hal tersebut menunjukkan bahwa wanita Hindu di Desa Pakraman Mas mampu menunjukkan eksistensi dalam kehidupan masyarakat di Desa Pakraman Mas. Wanita Hindu di Desa Pakraman Mas memiliki peran penting sebagai penggerak aktifitas yajna yaitu tergabung dalam kelompok serati banten. Wanita Hindu di Desa Pakraman Mas juga bertanggung jawab dalam perbaharuan informasi dalam membangun keluarga yang sejahtera yang tergabung dalam kelompok penggerak PKK. Wanita Hindu di Desa Pakraman Mas juga mempunyai tanggung jawab dalam pelestarian budaya Bali dengan menerapkan kegiatan ngayah dalam setiap pelaksanaan upacara yajna di Desa Pakraman Mas.

Wanita Hindu sederhana dalam beraktivitas dan mampu menerima pengaruh global. Wanita Hindu mampu mempertahankan akar budaya dan memegang teguh ajaran agama. Wanita ikut aktif dalam berbagai kegiatan dalam masyarakat (Sudarta, 2005:35). Wanita Hindu di Desa Pakraman Mas selalu berusaha mengembangkan daya kreatifitasnya untuk bisa tetap eksis dalam kehidupan bermasyarakat. Wanita Hindu di Desa Pakraman Mas selalu berusaha bergerak dinamis dan terbuka untuk bisa menerima perkembangan jaman dan tanpa meninggalkan warisan budaya yang telah dimiliki.

\section{Eksistensi Wanita Hindu dalam Dunia Kerja}

Wanita Hindu di Desa Pakraman Mas tidak hanya eksis dalam kehidupan keluarga dan masyarakat tetapi juga ikut menunjukkan eksistensinya di dunia kerja. Seiring perkembangan jaman dan ilmu pengetahuan, wanita Hindu di Desa Pakraman Mas tidak hanya menunjukkan eksistensi dalam keluarga dan masyarakat, tetapi juga di dunia kerja. Banyak wanita Hindu di Desa Pakraman Mas bekerja di rumah maupun di luar rumah untuk membantu keuangan keluarga atau bahkan menjadi tulang punggung keluarga. Ada yang bekerja sebagai pegawai suasta, pegawai negeri sipil, dan sebagai pengerajin seni patung. Kemampuan wanita Hindu di Desa Pakraman Mas I dunia kerja tidak kalah dengan kaum laki-laki. Setelah adanya perkembangan perandan posisi kaum wanita yang sejak dahulu telah menempatkan wanita sebagai mitra yang sejajar dengan kaum pria, maka fenomena wanita bekerja pada sektor pertanian bagi masyarakat bukanlah hal yang barudan bukanlah hal yang tidak mungkin terjadi (Rantung \& Memah, 2017).

Eksistensi wanita Hindu di Desa Pakraman Mas dalam dunia kerja tidak kalah dibandingkan kaum laki-laki. Perkembangan ilmu pengetahuan dan teknologi menuntut wanita Hindu di Desa Pakraman Mas untuk ikut berkembang agar tetap mampu memperlihatkan eksistensinya. Inovasi yang ditunjukkan wanita Hindu Desa Pakraman Mas mampu menunjukkan bahwa wanita Hindu di Desa Pakraman Mas adalah kelompok manusia yang dinamis yang terus berkembang untuk menunjukkan eksistensinya. Perkembangan ilmu pengetahuan dan teknologi menuntut manusia untuk mampu bertahan dan ikut berperan aktif dalam perkembangan pendidikan, ilmu pengetahuan, dan teknologi. Hal itu berarti bahwa kepentingan yang tercermin dalam kondisi seperti itu bisa dikatakan sebagai kepentingan yang ditujukan untuk kelangsungan hidup seluruh rumah tangga yang betul-betul berlawanan dengan kepentingan seorang anak perempuan yang ingin mempunyai upah sendiri dan bekerja dengan orang-orang yang sebaya dengan dirinya di luar rumah tangganya (Lestari, 2011).

Perkembangan ilmu pengetahuan dan teknologi membuat wanita Hindu di Desa Pakraman Mas ikut melakukan inovasi agar dapat ikut serta bersaing di dunia kerja. 
Penguasaan terhadap ilmu pengetahuan dan teknologi sangat membantu kaum wanita Hindu di Desa Pakraman Mas mempunyai daya saing di dunia kerja. Perkembangan ilmu pengetahuan dan teknologi juga mempengaruhi pola pikir masyarakat di Desa Pakraman Mas. Dulu wanita Hindu di Desa Pakraman Mas hanya diam di rumah dan hanya disibukkan oleh pekerjaan rumah, tapi kini banyak wanita Hindu di Desa Pakraman Mas yang ikut unjuk kebolehan di dunia kerja.

Perkembangan ilmu pengetahuan dan teknologi membantu wanita Hindu di Desa Pakraman Mas mengikuti dan berperan dalam perubahan jaman. Wanita Hindu di Desa Pakraman Mas kini tidak hanya bergelut dengan pekerjaan rumah tangga, tetapi juga mampu ikut berkiprah di dunia kerja. Dengan pemahaman dan penguasaan teknologi wanita Hindu di Desa Pakraman Mas lebih mudah menunjukkan eksistensinya di dunia kerja. Wanita Hindu di Desa Pakraman Mas ikut serta bersaing di dunia kerja dan mampu berada pada posisi yang setra dengan kaum laki-laki. Wanita Hindu di Desa Pakraman Mas kini menunjukkan eksistensinya dengan ikut bersaing di dunia kerja. Banyak posisi pekerjaan yang bisa diisi oleh wanita Hindu di Desa Pakraman Mas. Ada pekerjaan yang bisa dikerjakan di dalam rumah dan ada juga yang bekerja di luar rumah seperti sebagai tenaga pendidik negeri maupun swasta dan sebagai pegawai dibidang niaga.

Perubahan dalam kehidupan sosial masyarakat memang tidak dapat dielakan. Demikian juga dengan yang terjadi di Desa Pakraman Mas, kini wanita Hindu di Desa Pakraman Mas juga ikut bertanggung jawab salam keuangan keluarga. Bagi kaum wanita Hindu di Desa Pakraman Mas yang tidak bisa mencari pekerjaan di luar rumah, mereka juga ikut eksis dengan mencari pekerjaan yang bisa dikerjakan di rumah, missal sebagai pengerajin seni patung. Gambar tentang eksistensi wanita Hindu Desa Pakraman Mas yang bekerja di rumah. Wilbert Moore memandang peribahan sosial merupakan gejala yang sosial, pola perilaku, dan interaksi sosial. Perubahan sosial merupakan gejala yang melekat di setiap masyarakat (Setiadi, 2006 : 49). Perkembangan ilmu pengetahuan dan teknologi dapat mengubah perilaku dan pola pikir masyarakat. Perubahan sosial yang terjadi dapat bergerak kea rah yang bersifat positif atau malah sebaliknya. Perubahan sosial yang dilakukan oleh wanita Hindu di Desa Pakraman Mas merupakan salah satu perubahan sosial yang bergerak kearah yang positif. Kini wanita Hindu di Desa Pakraman Mas tidak hanya menunjukkan eksistensi di dalam keluarga dan masyarakat, tetapi juga ikut bersaing di dunia kerja. Wanita Hindu di Desa Pakraman Mas berusaha untuk selalu melakukan pembaharuan untuk menunjukkan eksistensinya di dalam keluarga, masyarakat maupun di dunia kerja.

Kiprah yang diperankan wanita Hindu di Desa Pakraman Mas dalam keluarga, masyarakat Mas merupakan wanita Hindu di Desa Pakraman Mas merupakan wanita Hindu yang mampu berkembang dan tetap eksis dalam perubahan jaman yang terjadi. Hal tersebut menunjukkan bahwa wanita Hindu di Desa Pakraman Mas merupakan kelompok manusia yang selalu berbuat dan terbuka dalam menerima perubahan yang terjadi, hal tersebut sesuai dengan asumsi dari teori eksistensialisme.

\section{SIMPULAN}

Eksistensi wanita Hindu di Desa Pakraman dapat dikelompokkan menjadi tiga. Eksistensi dalam menjalankan swadharma di masyarakat. Eksistensi dalam menjalankan swadharma di dunia kerja. Kendala yang dihadapi oleh wanita Hindu di Desa pakraman Mas dalam menjalankan swadharma yaitu, kurang bisa mengatur waktu dalam menjalankan swadharma, kurangnya pemahaman dalam mendidik anak di keluarga, dan keterbatasan kemampuan wanita dalam melaksanakan swadharma akibat sakit dan perkembangan usia. Upaya yang dilakukan wanita Hindu dalam menjalankan swadharma secara selaras yaitu, melakukan komunikasi, koordinasi dan kerja sama yang baik dengan orang lain dalam keluarga, masyarakat, dan di dunia kerja, serta selalu meingkatkan pemahaman dan kualitas diri agar mampu selalu melakukan yang terbaik. 


\section{DAFTAR PUSTAKA}

Budiadnya, I. P. (2016). Peran Guru Rupaka Dalam Menanamkan Ajaran Agama Hindu. Widya Aksara, 21(2).

Dewi, D. N. (2020). Peran Perempuan Hindu dalam Situasi Pandemi Covid 19. Sanjiwani: Jurnal Filsafat, 11(2), 219-231.

Djiwandono, S. E. W. (2005). Konseling dan Terapi dengan Anak dan Orang Tua. Jakarta: PT Grasindo.

Hyoscyamina, D. E. (2011). Peran keluarga dalam membangun karakter anak. Jurnal Psikologi, 10(2), 144-152.

Lestari, P. (2011). Peranan Dan Status Perempuan dalam Sistem Sosial. DIMENSIA: Jurnal Kajian Sosiologi, 5(1).

Manembu, A. E. (2017). Peranan Perempuan Dalam Pembangunan Masyarakat Desa (Suatu Studi Di Desa Maumbi Kecamatan Kalawat Kabupaten Minahasa Utara). Jurnal Politico, 6(1).

Moleong, L. J. (2001). Dasar-Dasar Penelitian Kualitatif. Bandung: Remaja Rosdakarya.

Muzairi. (2002). Eksistensialisme Jean Paul Sartre. Yogyakarta: Pustaka Pealajar.

Rakhmawati, I. (2015). Peran keluarga dalam pengasuhan anak. Jurnal Bimbingan Konseling Islam, 6(1), 1-18.

Rantung, V. V., \& Memah, M. Y. (2017). Peran Tenaga Kerja Wanita dalam Usahatani Hortikultura di Kelurahan Wailan, Tomohon Utara, Kota Tomohon. AGRISOSIOEKONOMI, 13(1A), 169-182.

Saptari, R. (1997). Perempuan, kerja, dan perubahan sosial: sebuah pengantar studi perempuan (Vol. 1). Jakarta: Pustaka Utama Grafiti.

Soedarsono \& Murniatmo, G. (1986). Nilai Anak dan Wanita Dalam Masyarakat Jawa. Yogyakarta: Depdikbud

Sofian, F. A. (2014). Makna komunikasi keluarga bagi wanita karier: Studi fenomenologi mengenai makna komunikasi keluarga bagi wanita karier di kota Bandung. Humaniora, $5(1), 468-482$.

Sudarta, W. (2003). Peranan Wanita Dalam Pembangunan Berwawasan Gender. Jurnal Studi Jender SRIKANDI

Surada, I M. (2009). Kamus Sanskerta-Indonesia. Surabaya : Paramita.

Wirartha, I. M. (2000). Ketidakadilan jender yang dialami pekerja perempuan di daerah pariwisata. SOCA: Jurnal Sosial Ekonomi Pertanian. 